\title{
Co-composting of green waste, food waste and phosphoric rock. Comparison of two-stage composting with traditional composting.
}

\section{Angelica Maria Hernandez-Gomez}

Universidad Industrial de Santander

\section{Marcos Ríos}

Universidad Industrial de Santander

\section{Anauribeth Portela}

Universidad Industrial de Santander

\section{Viviana Sánchez-Torres}

Universidad Industrial de Santander

\section{Isabel Domínguez}

Universidad Industrial de Santander

\section{Ricardo Oviedo-Ocaña ( $\nabla$ eroviedo@uis.edu.co)}

Universidad Industrial de Santander https://orcid.org/0000-0002-8970-7322

\section{Dimitrios Komilis}

Democritus University of Thrace

\section{Research}

Keywords: Co-composting, Green waste, Food waste, Phosphoric rock, Two-stage composting

Posted Date: June 18th, 2020

DOl: https://doi.org/10.21203/rs.3.rs-33757/v1

License: (9) This work is licensed under a Creative Commons Attribution 4.0 International License. Read Full License 


\section{Abstract}

Green waste (GW) co-composting has limitations due to the content of slowly degradable compounds (i.e. lignocellulosic substances). The introduction of amendment and bulking materials has improved organic matter degradation and end-product quality. However, recent studies have included additional strategies such as two-stage composting (TSC). This research evaluates the effect of TSC on the process and end-product quality of co-composting of GW, food waste, sawdust and phosphoric rock. In our knowledge, TSC has not been studied together with strategies like the addition of co-substrates such as FW and phosphoric rock to improve GW composting. A pilot-scale study was developed using two triplicate treatments: TA: TSC and TB: Traditional composting. The two treatments used the same mixture (wet weight): $46 \% \mathrm{GW}, 19 \%$ unprocessed food waste, $18 \%$ processed food waste, $13 \%$ sawdust, and $4 \%$ phosphoric rock. TB had a higher degradation rate of organic matter during the mesophilic and thermophilic phases compared to TA. This is related to the higher temperatures for longer periods during these two phases, with a higher degradation of volatile solids. Nonetheless, during the cooling and maturation phases, the two treatments had similar behavior on temperature, $\mathrm{pH}$, and electrical conductivity with ash and lignin contents without significant differences at the end of the process. Endproducts in both treatments lacked statistically significant differences and fulfill quality criteria for use as soil improvers. However, end-products from traditional composting had lower nutrient content $\left(\mathrm{N}_{\text {Total }}\right.$ and $\left.P_{\text {Total }}\right)$ that can be associated with nitrogen volatilization or the use of nutrients by the microorganisms during the active process phases. These results indicate that at the end of the process, there were no significant differences in the total processing time, degradation rate or end-product quality among TSC and traditional composting. Evaluation of complementary strategies must continue to improve GW composting.

\section{Introduction}

Green waste is an important fraction of municipal solid waste (MSW) [1]. Composting is an effective method to manage GW because it reduces its volume and generates a product rich in nutrients which can be used for soils and plants [2]. However, GW composting is a challenge due to the content of lignocellulosic substances, which are difficult to degrade by microorganisms [3,4]. This has led to fails in some GW composting plants due to the generation of immature products, plant under-sizing and odor emissions $[5,6]$.

The reduction of processing times and the improvement of end-product quality have become important goals of GW composting [6, 7]. Different studies have focused on GW composting optimization using different strategies [4, 8-10]: (i) operational changes on the process; (ii) addition of microbial inoculum; and (iii) co-composting with different supplementary materials (bulking or amendment) [7].

Regarding co-composting of GW, different materials have been used as amendments or bulking agents, such as: fly ash and jaggery [11], elemental sulfur [9], bio-char [12], bio-solids [8], wood chips [4], pig manure [13], cow dung (CD) and spent coffee grounds (SCG) [14]. The introduction of these materials 
aims to add essential nutrients, readily available carbon forms, compounds to regulate $\mathrm{pH}$ or control moisture. These additives have increased microbial activity, accelerated organic matter degradation, and improved end-product quality $[10,11,15]$.

Likewise, the low content of phosphorous, characteristic of GW composting, has been adjusted adding phosphoric rock (PR), that besides improving end-product quality, reduces nitrogen volatilization $[5,9]$. However, PR must be added in concentrations that do not inhibit the process [16] or excessively increase its content in the end-product [17].

Despite the variety of amendment materials used in GW composting, the literature assessing the addition of food waste (FW) is scarce. FW has several advantages as amendment material $[1,18]$ : i) FW is continually available in the MSW flow which is important when limitations to acquire other co-substrates exist; ii) FW has a high content of readily available organic matter that complements the physicochemical characteristics of GW; iii) FW provides essential nutrients such as nitrogen and potassium. In addition, cocomposting of GW and FW simultaneously addresses the management of these two types of waste which together represent the higher proportion of MSW in developing countries [19].

Previous studies that used processed food waste (PFW) and unprocessed food waste (UPFW) $[1,16]$ on GW composting show a reduction of processing times in the mesophilic and thermophilic phases compared to composting of GW only, and improved end-product quality that better fulfills the Colombian quality standards for biofertilizers. However, the cooling and maturation phases (i.e. when the degradation of lignocellulosic substances occur) have shown temperature behavior and processing times similar to the composting of only GW. These studies show the need to introduce additional strategies that contribute to increase the degradation rate of lignocellulosic substances and help to reduce the total processing time.

Operational modifications to the process are another strategy to improve GW composting $[4,10]$. One of these strategies is two-stage composting (TSC). This method results in two peaks in the composting temperature (at $55-60{ }^{\circ} \mathrm{C}$ or even higher) and a longer thermophilic period. As a consequence, the production of a mature and stable compost requires only 30 days rather than the 90-270 days required for traditional composting [10]. However, in our knowledge, TSC has not been studied together with strategies like the addition of co-substrates such as FW and PR to improve GW composting.

This research evaluates the effect of the TSC on the process and quality of end-product in the cocomposting of GW, FW, sawdust (SW) and PR, considering that: i) the mixture of GW and FW has been beneficial for the process and end-product quality of composting [1]; ii) SW have proved to be a bulking agent appropriate for GW composting [4]; iii) phosphorous must be used in the co-composting of GW and FW due to their deficiencies in the product $[5,9,16]$; and iv) additional strategies for co-composting need to be assessed such as TSC $[4,10]$.

\section{Materials And Methods}




\subsection{Experimental setup}

We developed a pilot-scale composting experiment using two treatments to assess the effect of TSC on the process and end-product quality of co-composting of GW, FW, PR and SW. Treatment A (TA) was TSC and Treatment B (TB) was Traditional Composting. The two treatments had triplicate experimental units of $200 \mathrm{~kg}$. The treatments had the same mixture of materials (wet weight): $46 \% \mathrm{GW}, 19 \%$ UPFW, $18 \%$ PFW, $13 \%$ SW, and $4 \%$ PR. The mixture was defined based on previous studies $[1,16]$, considering two criteria: i) predominance of $\mathrm{GW}$ on the mixture, and ii) $\mathrm{C} / \mathrm{N}$ ratio around 20.

- FW was introduced as amendment material to provide readily degradable organic matter (i.e. simple carbohydrates) and nitrogen.

- PR was added as bulking agent and material amendment, providing porosity and phosphorus. The amount added was considered taking into account previous studies $[5,9,16]$.

- The SW was added as a source of carbon and as a bulking agent.

GW was obtained from the maintenance of green areas of a university campus and had the following physical composition: $35 \%$ leaves, $26 \%$ grass clippings, $20 \%$ soil extract, $9 \%$ tree branches, $3 \%$ fruit, $1 \%$ roots and $6 \%$ non-biodegradable materials. Before the experimental setup, non-biodegradable materials were removed (e.g. stones, plastics). GW was stored for one or two weeks. UPFW and PFW were sourceseparated and were collected, using composite sampling, from a university restaurant, where approximately 3,000 lunches per day are normally prepared. Both substrates were stored for three days. PR and SW were provided by local suppliers. GW and FW were manually crushed to achieve particle size between 5 and $7 \mathrm{~cm}$. Later, they were manually mixed and homogenized using shovels.

The experiment was developed in the campus of Universidad Industrial de Santander (Bucaramanga, Colombia) (average temperature of $24^{\circ} \mathrm{C}$ ). The experimental setup was developed in a covered area with concrete floor. All piles were run simultaneously to maintain similar environmental conditions during the experiments.

According to previous studies [16], TSC was carried out in the following way: i) in the first stage, wooden containers $(0.55 \times 1.3 \times 1.25 \mathrm{~m})$ were used to confine the mixture, the containers had holes of $5 \mathrm{~cm}$ diameter and four perforated pipes (1.4 m high), both to maintain the necessary aerobic conditions for the process. This stage ended when the first thermophilic phase was completed; ii) in the second stage, the material was removed from the containers and piles in conical heaps. In the second stage, a second thermophilic phase was expected, and the completion of the process when the material reached ambient temperature [10]. During the process the material was removed from the containers on the tenth day to start the second stage of the process. Traditional composting was carried out in conical heaps of $1 \mathrm{~m}$ height.

\subsection{Process monitoring}


The parameters monitored were: temperature, $\mathrm{pH}$, electrical conductivity (EC), moisture, oxygen concentration, volatile solids (VS), germination index (GI) and self-heating. Monitoring started right after the preparation of the piles. Temperature was measured daily on the compost pile centroid, using a $60-\mathrm{cm}$ thermometer (i.e. digital thermometer K-Type HI935005N with high accuracy $( \pm 0.2 \%)$ ). Subsamples taken from four opposite locations in each compost pile were combined to form a $200 \mathrm{~g}$ sample that was specifically used for $\mathrm{pH}, \mathrm{EC}$, moisture and VS measurements [20, 21].

$\mathrm{pH}$ and EC were measured at least three times a week for the first two weeks and then twice a week at least, until the end of the monitoring. These parameters were potentiometrically measured to an aqueous extract obtained from a stirred mixture of the sample and distilled water (1:10 w/v). Measurement was carried out using a desk pHmeter and EC ionometer, sensIONTM + MM374. Moisture was measured by drying in an oven a $50 \mathrm{~g}$ sample at $105^{\circ} \mathrm{C}$ for $24 \mathrm{~h}$; this parameter was measured three times a week up to day 42 , and later twice a week up to the end of the process. VS were measured, by burning a dried sample at $550{ }^{\circ} \mathrm{C}$ in an oven for $4 \mathrm{~h}$. The Total Organic Carbon (TOC) was calculated from the ash content [22].

Pile monitoring was performed until one of the piles reached ambient temperature $\left(24 \pm 2{ }^{\circ} \mathrm{C}\right)$ (i.e. day 73). Before to the completion of the experiment, on-site self-heating tests were performed to determine if temperature rises occurred when piles were moisturized [23]. In addition, stability was evaluated by the self-heating test using Dewar flasks of $1.5 \mathrm{~L}$ of volume according to Brinton et al. [24].

Maturity evolution was established through germination test during the process. The germination index was determined by the methodology established by Varnero et al. [25]. A fresh sample was extracted with distilled water at compost to water ratio 1:10 (w/v), shook, allowed to stand for $3 \mathrm{~h}$ and then filtered. Subsequently, $10 \mathrm{~mL}$ of extract were placed in $9 \mathrm{~cm}$ Petri dishes containing ten seeds of radish on filter paper. Experiments were conducted in triplicates and distilled water was used as control. This test was performed on the days 47,53 and 60 .

Oxygen was provided to the piles through manual turning in the two treatments. Daily turning frequency was used for the two treatments up to day eight of process. Later, turning was performed according to the process requirements (i.e. every two days up to day 25 , and then, every three days up to day 37 , and lastly once a week until day 73). The Oxygen concentration (OC) was controlled using a probe CM37 (i.e. twice a week until day 37 and once a week until the end of the process).

\subsection{End-product quality evaluation}

At the end of the composting process, manual sieving of the products was carried out using a $1.25 \mathrm{~cm}$ sieve. A representative sample of each experimental unit was taken to carry out product quality analysis. Samples were analyzed at the laboratory of the Interdisciplinary Group of Molecular Studies from Universidad de Antioquia, following the methods described in the Colombian Technical Norm (NTC) 5167 [26]. Table 1 presents the parameters analyzed and the techniques used. Finally, the characteristics of the products obtained were analyzed and compared with the standards from NTC 5167 for organic products 
used as fertilizers and soil amendments or conditioners. The Lignin content was quantified using the Neutral detergent fiber (NDF), acid detergent fiber (ADF) and acid detergent lignin (ADL), considering the procedures established by Van Soest et al. [27].

Table 1

Methods used for product characterization

\begin{tabular}{|lll|}
\hline Parameters & Units & Method / Technique \\
\hline $\mathrm{pH}$ & -- & Potentiometric \\
\hline Moisture & $\%$ & Gravimetric \\
\hline Total Organic Carbon $(\mathrm{TOC})$ & $\%$ & Gravimetric \\
\hline Total Nitrogen $(\mathrm{N})$ & $\% \mathrm{dw}$ & Titrimetric Kjeldahl \\
\hline Ash & $\% \mathrm{dw}$ & Gravimetric \\
\hline Total Potassium $\left(\mathrm{K}_{2} \mathrm{O}\right)$ & $\% \mathrm{dw}$ & Atomic absorption \\
\hline Total Phosphorous $\left(\mathrm{P}_{2} \mathrm{O}_{5}\right)$ & $\% \mathrm{dw}$ & Spectrophotometric \\
\hline Electrical Conductivity & $\mathrm{mS} \mathrm{cm}{ }^{-1}$ & Potentiometric \\
\hline Cation exchange capacity & $\mathrm{cmol} \mathrm{kg}$ & Volumetric \\
\hline Water retention capacity & $\%$ & Gravimetric \\
\hline Volatile Solids & $\% \mathrm{dw}$ & Gravimetric \\
\hline Note: dw. dry weight & & \\
\hline
\end{tabular}

All the experiments were carried out in triplicate. Data were subjected to one-way analysis of variance ANOVA and the significantly different means were evaluated using Least Significant Difference (LSD) with a significance level $a=0.05$, using the software $R \circledast$.

\section{Results And Discussion \\ 3.1 Process conditions}

Figure 1 presents the temperature in the two treatments. The time to reach the maximum temperature, the duration of the thermophilic phase and the time to reach ambient temperature are presented in Table 2. Temperature increases due to microbial activity. [28]. In both treatments, the typical sequential phases: mesophilic, thermophilic, cooling and maturation were observed (see Fig. 1). Besides, TA had two thermophilic peaks after the extraction of the mixture from the container (i.e. day 10). These peaks are characteristic of TSC $[4,10]$. 
Table 2

Synthesis of characteristics of the composting process in the experiment

\begin{tabular}{|c|c|c|c|c|c|c|c|}
\hline Treatment & $\begin{array}{l}\text { Mesophilic } \\
\text { phase } \\
\text { duration (d) }\end{array}$ & $\begin{array}{l}\text { Thermophilic } \\
\text { phase } \\
\text { duration (d) }\end{array}$ & $\begin{array}{l}\text { Tmax } \\
\left({ }^{\circ} \mathrm{C}\right)\end{array}$ & $\begin{array}{l}\text { Time to } \\
\text { reach } \\
\text { Tmax } \\
\text { (d) }\end{array}$ & $\begin{array}{l}\text { Cooling } \\
\text { phase } \\
\text { duration } \\
\text { (d) }\end{array}$ & $\begin{array}{l}\text { VS } \\
\text { reduction } \\
\text { (\%) }\end{array}$ & $\begin{array}{l}\text { Added } \\
\text { water } \\
\text { (L) }\end{array}$ \\
\hline TA & 1 & 27 & 62.6 & 6 & 46 & $\begin{array}{l}40.4 \\
(2.2)\end{array}$ & 148.3 \\
\hline TB & 1 & 33 & 68.6 & 12 & 40 & $\begin{array}{l}38.5 \\
(7.6)\end{array}$ & 120.0 \\
\hline
\end{tabular}

Both treatments had a rapid increase on temperature, achieving thermophilic phase in day 1 of the process, similar to findings from other GW co-composting studies $[1,5]$. This rapid temperature increase evidences adequate conditions for the process regarding the studied substrate mixture (i.e. $\mathrm{pH}$, moisture, TOC, nutrients, porosity). In day 2 , the temperature increase was higher in TA $\left(54^{\circ} \mathrm{C}\right)$ compared to TB $\left(46^{\circ} \mathrm{C}\right.$ ), showing the influence of this modification in the process (i.e. possibly associated to the reduced heat lost in the mixture inside the container). However, from day three to day 20 , the temperature in TB was higher than in TA, showing a higher organic matter degradation rate in this period. Despite having a higher reduction in VS by day 24 in TB compared to TA (i.e. $25.9 \%$ in TB and $25.5 \%$ in TA) the difference is not considered substantial.

After day 3, continuous oscillations of temperature occurred in both treatments. However, in TA there was a pronounced reduction after day 5 and until the material was removed from the container (day 10), with a new temperature increase. Thus, the two typical thermophilic temperature peaks for the TSC were observed $[4,10]$. By day 12 , the two temperature peaks and the subsequent decrease occurred in both treatments. The thermophilic phase lasted $27 \mathrm{~d}$ in TA and $33 \mathrm{~d}$ in TB, showing the influence of the process type on the degradation of the organic matter readily degradable (i.e. mesophilic and thermophilic phases). It is important to emphasize that by day 32, there was a reduction in VS in $29.0 \%$ in TB and $27.2 \%$ in TA, which ratifies the higher biological activity and thus, the higher transformation of organic matter in the traditional composting compared to TSC. As expected, in both treatments there was a higher degradation rate on the mesophilic and thermophilic phases compared to the cooling and maturation phases. This is due to the decomposition of the readily degradable organic matter in the first phases, and the decomposition of recalcitrant organic matter (lignin and cellulose) in the final phases [29].

In both treatments, the temperatures were above $50{ }^{\circ} \mathrm{C}$ for more than three consecutive days, promoting the material sanitization [30]. Furthermore, TB fulfill the recommendations from Böhm [31], who indicates that temperature should be at least higher than $55^{\circ} \mathrm{C}$ at least for two weeks (TB:16 d and TA: $12 \mathrm{~d}$ ). The 
higher temperature values in TB are ascribed mainly to the aeration conditions in the containers. Although, the temperature increase was faster in TSC, higher temperatures maintained longer were observed in traditional composting, showing higher organic matter degradation rates in the thermophilic and mesophilic phases (i.e. evidenced in the VS reduction).

The favorable conditions for degradation in both treatments can be connected to the incorporation of PR, characterized for promoting the generation of heat due to the increase in porosity and the provision of the oxygen required for aerobic degradation [5].

On the other hand, during the thermophilic phase, higher nitrogen losses could occur due to $\mathrm{NH}_{3}$ volatilization (i.e. associated to high temperatures and alkaline $\mathrm{pH}$ ), mainly in TB (i.e. turning also promotes this loss), as observed in the end-product quality records (see Table 3) [32, 33]. In this case, TSC reduced nitrogen volatilization possibly associated with the storage of the material within the containers during the ten first days.

The temperature in the two treatments had similar values in the cooling phase, especially after day 36 , with variations associated with pile turning. This behavior can indicate that decomposition of hard to degrade substances in this phase was similar in both treatments. Thus, the influence of TSC in accelerating the degradation of lignocellulosic substances in the composting process was not observed. This was ratified on the final average values of the VS reduction, that was $40.4 \%$ in TA and $38.5 \%$ in TB, showing similar degradation rates (i.e. there were not statistical significant differences).

Regarding pH (see Fig. 2), the mixture of substrates in both treatments showed an initial pH with slightly acidic values, due to the previous degradation of some materials (e.g. UPFW-4.3 units and PFW-4.1 units) which had 3 storage days before the experiment start. This degradation leads to the formation of volatile fatty acids which reduce substrate $\mathrm{pH}$ and could affect the process start [34]. However, in both treatments $\mathrm{pH}$ increased rapidly as a consequence of the transformation of organic matter in organic acids (intermediate byproducts of the microbial decomposition of sugars, starch and lipids) and later the volatilization of products such as $\mathrm{CO}_{2}$ [35]. Small variations in the $\mathrm{pH}$ were observed during the process associated with its conditions of moisture and oxygenation. However, the $\mathrm{pH}$ in the process was between 8 and 9 units as suggested by some authors for optimal microbial degradation [36]. At the end of the process, the $\mathrm{pH}$ had average values of 7.3 units in both treatments (i.e. there were not statistical significant differences).

Figure 3 presents the average EC in both treatments. EC indicates the presence of salts due to the content of sodium, chloride, potassium, nitrate, sulfate and ammonium salts, which in high concentrations could inhibit plant growth [37]. The relatively high EC values from the start of the process could be associated to the presence of soluble salts (i.e. phosphates) due to the addition of PR. The small increase observed at the end of the process could be connected to the effect of the material degradation with the processes of humification and nutrients liberation (i.e. nitrates). Higher values of EC were observed in TSC compared to traditional composting possibly linked to a higher concentration of phosphates in the 
material (see Table 3). In the case of TB, the decomposition rate of the readily degradable organic matter in the early stages of the process led to a higher nutrient liberation from the start of the process (i.e. lower values of $\mathrm{N}$ and $\mathrm{P}$ in the products). As indicated by Tiquia [38], salinity could be connected to the relatively high content of $\mathrm{N}_{\text {Total }}$ in the end-product as reported for TA. In both treatments, the ranges recommended by Dimambro et al. [39] to avoid toxicity for plants and crops were not surpassed.

The seed germination test has been widely used for evaluating compost quality, since the application of an unstable and immature compost could inhibit the germination of seeds, reduce plant growth and damage the crops [40,41]. A germination index (GI) higher to $80 \%$ indicates that compost is not phytotoxic $[25,42]$. In both treatments, the products were mature in the three measurements developed (i.e. days 47, 53 and, 60 ), with higher values at the end of the process in TB piles ( $\mathrm{GI}=160 \%$ ) compared to TA piles $(\mathrm{GI}=150 \%)$. This could be associated with the lower content of salts or phytotoxic substances measured through the EC parameter [40].

\subsection{Product quality}

Table 3 presents the information on end-product quality for both treatments. In addition, it includes a comparison of quality standards according to the NTC 5167 and other studies about GW co-composting.

Regarding moisture, both treatments had values about those established by the NTC 5167. These relatively high values are associated with the moisturizing carried out 10 days before the end of the process in all piles. Likewise, the values agreed with those reported in previous studies $[1,16]$. Comparing end-product moisture in both treatments there were no statistically significant differences.

The values of $\mathrm{pH}$ were within the range established by the NTC 5167 for the use of products as soil improvers. The $\mathrm{pH}$ was slightly alkaline (around neutral values), which favors their application in acid soils facilitating carbon mineralization, generation of $\mathrm{OH}^{-}$ions and introduction of basic cations such as $\mathrm{K}^{+}$[43]. The results obtained are similar to those reported for co-composting processes of GW and FW [1, 16]. The smaller values of $\mathrm{pH}$ found in this study could be related to the addition of PR, since its dissolution improves the formation of organic acids of low molecular weight and the generation of $\mathrm{CO}_{2}$ during the degradation of organic waste [44]. Furthermore, $\mathrm{PR}$ can also reduce the $\mathrm{pH}$ for the adsorption of $\mathrm{NH}_{3}$ and cations $[5,45]$.

Table 3 End-product quality characteristics for both treatments 


\begin{tabular}{|c|c|c|c|c|c|c|c|c|}
\hline Parameters & Units & $\mathrm{TA}(\mathrm{n}=3)$ & TB $(n=3)$ & $\begin{array}{l}\text { NTC } \\
5167\end{array}$ & $\begin{array}{l}\text { Hernández et } \\
\text { al. [16] }\end{array}$ & $\begin{array}{c}\text { Oviedo-Ocaña } \\
\text { et al. [1] }\end{array}$ & $\begin{array}{c}\text { Boldrin et } \\
\text { al. [46] }\end{array}$ & $\begin{array}{c}\text { Zhang and } \\
\text { Sun [6] }\end{array}$ \\
\hline Moisture & $\%$ & $\begin{array}{l}45.70 \\
(3.59)\end{array}$ & $\begin{array}{l}44.20 \\
(1.13)\end{array}$ & $<35$ & 33.87 & 54.6 & $29-44$ & -- \\
\hline $\mathrm{pH}$ & Units & $\begin{array}{c}7.39 \\
(0.17)\end{array}$ & $\begin{array}{c}7.34 \\
(0.57)\end{array}$ & $\begin{array}{l}>4- \\
<9\end{array}$ & 7.51 & 7.60 & -- & 7.9 \\
\hline $\begin{array}{l}\text { Total organic } \\
\text { carbon }\end{array}$ & $\% d w$ & $\begin{array}{l}28.16 \\
(0.85)\end{array}$ & $\begin{array}{l}29.04 \\
(1.58)\end{array}$ & $>15$ & 20.87 & 23.1 & $10-19$ & 25 \\
\hline Total Nitrogen & $\% d w$ & $\begin{array}{c}1.76 \\
(0.32)\end{array}$ & $\begin{array}{c}1.55 \\
(0.31)\end{array}$ & $>1$ & 1.37 & 2.35 & $0.7-0.9$ & 3.0 \\
\hline $\mathrm{C} / \mathrm{N}$ & - & $\begin{array}{l}15.97 \\
(4.09)\end{array}$ & $\begin{array}{l}18.68 \\
(7.19)\end{array}$ & - & 14.9 & -- & $11-27$ & -- \\
\hline $\begin{array}{l}\text { Cation exchange } \\
\text { capacity }\end{array}$ & $\begin{array}{l}\mathrm{cmol} \\
\mathrm{kg}^{-1}\end{array}$ & $\begin{array}{l}38.13 \\
(6.71)\end{array}$ & $\begin{array}{l}32.70 \\
(7.05)\end{array}$ & $>30$ & 32.77 & -- & -- & -- \\
\hline $\begin{array}{l}\text { Electric } \\
\text { conductivity }\end{array}$ & $\mathrm{dS} \mathrm{m}_{1}^{-}$ & $\begin{array}{c}0.93 \\
(0.23)\end{array}$ & $\begin{array}{c}0.62 \\
(0.14)\end{array}$ & - & 0.21 & 1.66 & -- & 2.61 \\
\hline $\begin{array}{l}\text { Water retention } \\
\text { capacity }\end{array}$ & $\%$ & $\begin{array}{l}157.00 \\
(19.26)\end{array}$ & $\begin{array}{l}141.53 \\
(11.99)\end{array}$ & $>100$ & 237.4 & -- & -- & -- \\
\hline Density & $\begin{array}{l}\mathrm{g} \mathrm{cm}^{-} \\
3\end{array}$ & $\begin{array}{c}0.50 \\
(0.11)\end{array}$ & $\begin{array}{c}0.46 \\
(0.04)\end{array}$ & $<0,6$ & -- & -- & -- & -- \\
\hline $\begin{array}{l}\text { Total } \\
\text { Phosphorous }\end{array}$ & $\% d w$ & $\begin{array}{c}4.75 \\
(2.81)\end{array}$ & $\begin{array}{c}4.19 \\
(0.44)\end{array}$ & $>1$ & 0.56 & 0.8 & $\begin{array}{l}0.15- \\
0.23\end{array}$ & 0.3 \\
\hline Ash & $\% d w$ & $\begin{array}{l}52.10 \\
(4.09)\end{array}$ & $\begin{array}{l}55.40 \\
(7.92)\end{array}$ & $<60$ & 51.60 & -- & $72-79$ & -- \\
\hline Lignin & $\% d w$ & $\begin{array}{l}30.30 \\
(2.28)\end{array}$ & $\begin{array}{l}28.60 \\
(1.67)\end{array}$ & -- & -- & -- & -- & -- \\
\hline
\end{tabular}

Note: n: number of samples; dw. dry weight; Standard deviation is in parenthesis; all means (compared in the same row) are statistically similar at $\mathrm{p}<0.05$

Regarding TOC, both treatments showed higher values compared to those required by the Colombian Norm as soil improver [26]. These higher values could be connected to the carbon content still available to transform due to the presence of lignocellulosic compounds in the GW. Similar values were reported in previous studies from the authors $[1,16]$. The products did not have a statistical significant differences. Therefore, it is not possible to attribute this smaller content as an influence of TSC in the process.

Nitrogen had values higher than $1 \%$ in both treatments, which is favorable for product use in agricultural activities. There was a smaller concentration of $\mathrm{N}$ in TB compared to TA, but lacked of statistical significance. This smaller concentration is possibly linked to a higher $\mathrm{N}$ volatilization during the first two phases of the process. This is evident in the high temperatures in TB during the first 10 days combined with alkaline $\mathrm{pH}$ that promotes $\mathrm{NH}_{3}$ volatilization during turning [34]. On the other hand, relatively high values of $\mathrm{N}$ in both treatments could be connected to the high porosity that PR could provide to absorb $\mathrm{NH}_{3}$ and improve $\mathrm{N}$ conservation during the process $[47,48]$. 
Ash content was lower than $60 \%$ in both treatments, according to the requirements of the NTC 5167 , and lacked significant statistical differences comparing TA and TB. However, TB had relatively higher values compared to TA which can be linked to the intense organic matter degradation during the first 10 days, which are reflected in mass loss in the form of $\mathrm{CO}_{2}$ [49]. This high degradation can also be associated with the addition of PR in both treatments that provide nutrients and energy for microorganisms, accelerating transformation processes [5]. The addition of PR increased the quantity of inorganic material in both end-products, associated to phosphorous mineralization, and thus, intervene in the reported ash content in both treatments in contrast with our previous studies where this amendment material was not introduced [1].

The Cation Exchange Capacity (CEC) is used to evaluate the humification degree and nutrient retention capacity of compost. In both treatments, CEC was higher compared to the standard of NTC 5167 for soil improvers [26]. Despite the fact, there was not statistical significant differences, there were higher values in TA compared to TB possibly due to an increase in the humification processes in GW during the cooling and maturation phases, evidenced in a lower OC content at the end of the process. The results show that in both treatments, the end-products are able to improve the water and nutrient retention capacity of soils $[4,5]$.

The water retention capacity for a mature product must be higher to $100 \%$ [26] or $75 \%$ wet weight [50]. This parameter allows stablishing the product capacity to retain moisture, which is fundamental during the use of the product for agricultural purposes. The treatments had higher values compared to those established by the literature without statistical significant differences comparing TA and TB. The high water retention capacity in these products is connected to their low density (i.e. density was $0.50 \mathrm{~g} \mathrm{~cm}^{-3}$ for TA and $0.46 \mathrm{~g} \mathrm{~cm}^{-3}$ for TB) and high porosity of materials such as $\mathrm{GW}$, and to the processes of transformation and mineralization of organic matter.

Finally, the phosphorous content in TA and TB was higher to the standard from the NTC 5167 for soil improvers [26]. According to Khan and Joergensen [51], the solubilization of PR could increase microbial biomass to release inorganic phosphorous. The high porosity of PR could also provide and habitat to the high microbial biomass $[9,52] . P$ is a central component of the energy-carrying molecule (adenosine triphosphate, ATP) in all cells; increased P availability resulting from PR addition may increase the formation of ATP during microbial activity and reproduction, and therefore enhance the decomposition of organic waste $[5,53]$. Therefore, an increase on the microbial biomass during composting could contribute with an increase in the organic content of $\mathrm{C}$ and $\mathrm{P}$ in the end-product, as evidenced in the results from both products. Despite the fact, there were not statistical significant differences between the treatments, there were smaller values of $P$ in TB, which can be associated to a more intense activity of organic matter degradation during the first two phases of the process in the traditional composting.

\section{Conclusions}

The conclusions of this work are: 
- Traditional composting had higher biodegradation rates during the mesophilic and thermophilic active composting phases than the Two Stage Composting (i.e. higher temperatures reached for longer periods and a higher reduction of volatile solids). However, during the cooling and maturation phases, both treatments showed similar process conditions as these were judged by the temperature, volatile solids, $\mathrm{pH}$, and electrical conductivity.

- The twelve parameters measured here (moisture, $\mathrm{pH}$, electric conductivity, total organic carbon, total nitrogen, $\mathrm{C} / \mathrm{N}$ ratio, cation exchange capacity, water retention capacity, density, ash, total phosphorous, and lignin) on the end-products resulting from both the two-stage composting and traditional composting did not statistically differ. Both end-products could be used as soil improvers.

- Two-stage composting of green waste, food waste, phosphoric rock and sawdust at the end of the process did not influence of the processing time, degradation rate or end-product quality compared with traditional composting. Additional complementary strategies must be evaluated to improved GW composting.

\section{Declarations}

\section{Availability of data and materials}

All data generated or analyzed during this study are within the submitted manuscript.

\section{Competing interests}

The authors declare they have no competing interests.

\section{Funding}

This project was financed by the Universidad Industrial de Santander (Colombia) through project 2354 of 2017

\section{Authors' contributions}

All authors read and approved the final manuscript.

\section{Acknowledgements}

The authors wish to thank the Universidad Industrial de Santander for the support to carry out this work.

\section{Authors' information (optional)}

None.

\section{References}


1. Oviedo-Ocaña ER, Dominguez I, Komilis D, Sánchez A. Co-composting of green waste mixed with unprocessed and processed food waste: influence on the composting process and product quality. Waste Biomass Valorization. 2019;10:63-74.

2. Awasthi MK, Pandey AK, Khan J, Bundela PS, Wong JWC, Selvam A. Evaluation of thermophilic fungal consortium for organic municipal solid waste composting. Bioresour Technol. 2014;168:21421.

3. Yu K, Li S, Sun X, Cai L, Zhang P, Kang Y, et al. Application of seasonal freeze-thaw to pretreat raw material for accelerating green waste composting. J Environ Manag. 2019;239:96-102.

4. Zhang L, Sun X. Influence of bulking agents on physical, chemical, and microbiological properties during the two-stage composting of green waste. Waste Manag. 2016;48:115-26.

5. Zhang L, Sun X. Addition of fish pond sediment and rock phosphate enhances the composting of green waste. Bioresour Technol. 2017;233:116-26.

6. Zhang L, Sun X. Improving green waste composting by addition of sugarcane bagasse and exhausted grape marc. Bioresour Technol. 2016;218:335-43.

7. Reyes-Torres M, Oviedo-Ocaña ER, Dominguez I, Komilis D, Sánchez A. A systematic review on the composting of green waste: feedstock quality and optimization strategies. Waste Manag. 2018;77:486-99.

8. Belyaeva ON, Haynes RJ. Chemical, microbial and physical properties of manufactured soils produced by co-composting municipal green waste with coal fly ash. Bioresour Technol. 2009;100:5203-09.

9. Bustamante MA, Ceglie FG, Aly A, Mihreteab HT, Ciaccia C, Tittarelli F. Phosphorus availability from rock phosphate: combined effect of green waste composting and sulfur addition. J Environ Manag. 2016;182:557-63.

10. Zhang L, Sun X, Tian Y, Gong X. Effects of brown sugar and calcium superphosphate on the secondary fermentation of green waste. Bioresour Technol. 2013;131:68-75.

11. Gabhane J, William SP, Bidyadhar R, Bhilawe P, Anand D, Vaidya AN, et al. Additives aided composting of green waste: effects on organic matter degradation, compost maturity, and quality of the finished compost. Bioresour Technol. 2012;114:382-88.

12. Zhang $L$, Sun $X$. Changes in physical, chemical, and microbiological properties during the two-stage co-composting of green waste with spent mushroom compost and biochar. Bioresour Technol. 2014;171:274-84.

13. Arias 0 , Viña S, Uzal M, Soto M. Composting of pig manure and forest green waste amended with industrial sludge. Sci Total Environ. 2017;586:1228-36.

14. Zhang L, Sun X. Using cow dung and spent coffee grounds to enhance the two-stage co-composting of green waste. Bioresour Technol. 2017;245:152-61.

15. Himanen M, Hänninen K. Effect of commercial mineral-based additives on composting and compost quality. Waste Manag. 2009;29:2265-73. 
16. Hernández-Gómez A, Calderón A, Medina C, Sanchez-Torres V, Oviedo-Ocaña E R. Implementation of strategies to optimize the co-composting of green waste and food waste in developing countries. $A$ case study: Colombia. Environ Sci Pollut Res. 2020;1-7.

17. Vandecasteele B, Willekens K, Steel H, D'Hose T, Van Waes C, Bert W. Feedstock mixture composition as key factor for $\mathrm{C} / \mathrm{P}$ ratio and phosphorus availability in composts: role of biodegradation potential, biochar amendment and calcium content. Waste Biomass Valorization. 2017;8:2553-67.

18. Kumar M, Ou YL, Lin JG. Co-composting of green waste and food waste at low $\mathrm{C} / \mathrm{N}$ ratio. Waste Manag. 2010;30:602-09.

19. Troschinetz AM, Mihelcic JR. Sustainable recycling of municipal solid waste in developing countries. Waste Manag. 2009;29:915-23.

20. Benito M, Masaguer A, Moliner A, De Antonio R. Chemical and physical properties of pruning waste compost and their seasonal variability. Bioresour Technol. 2006; 97: 2071-76.

21. Sullivan DM, Miller RO. Compost quality attributes, measurements, and variability. In: Stoffella PJ, Kahn BA, editors. Compost Utilization in Horticultural Cropping Systems. Boca Raton: Lewis Publishers; 2001. p. 95-120.

22. Zeng G, Yu M, Chen Y, Huang D, Zhang J, Huang H, et al. Effects of inoculation with Phanerochaete chrysosporium at various time points on enzyme activities during agricultural waste composting. Bioresour Technol. 2010;101:222-27.

23. Dulac N. The organic waste flow in integrated sustainable waste management. In: Scheinberg A, editor. Tools for Decision-Makers-Experiences from the Urban Waste Expertise Programme (19952001). Nieuwehaven: WASTE; 2001.

24. Brinton WF, Evans E, Droffner ML, Brinton RB. A standardized Dewar test for evaluation of compost self-heating. BioCycle 1995;36:1-16.

25. Varnero MMT, Rojas AC, Orellana RR. Phytotoxicity indices of organic residues during composting. Rev Ciencia Suelo Nutr Vegetal 2007;7:28-37 [in Spanish].

26. ICONTEC. Norma Técnica Colombiana NTC 5167. Productos para la industria agrícola. Productos orgánicos usados como abonos o fertilizantes y enmiendas de suelo. Bogotá: Instituto Colombiano de Normas Técnicas y Certificación; 2004.

27. Van Soest PJ, Robertson JB, Lewis BA. Methods for Dietary Fiber, Neutral Detergent Fiber, and Nonstarch Polysaccharides in Relation to Animal Nutrition. J Dairy Sci. 1991;74:3583-97.

28. Chiumenti A, Chiumenti R, Diaz LF, Savage G, Eggerth L, Goldstein N. Modern Composting Technologies. Singapore: Journal of Composting and Organics Recycling; 2005.

29. Gong X, Li S, Sun X, Zhang L, Zhang T, Wei L. Maturation of green waste compost as affected by inoculation with the white-rot fungi Trametes versicolor and Phanerochaete chrysosporium. Environ Technol. 2017;38:872-79.

30. Haug RT. The practical handbook of compost engineering. Boca Raton: CRC Press; 1993. 
31. Böhm R. Pathogenic Agents. In: Diaz LF, de Bertoli M, Bidlingmaier W, editors. Compost Science and Technology. The Netherlans: Waste Management Series; 2007.

32. Wang J, Liu Z, Xia J, Chen Y. Effect of microbial inoculation on physicochemical properties and bacterial community structure of citrus peel composting. Bioresour Technol. 2019;291:121843.

33. Zhang L, Sun X. Addition of seaweed and bentonite accelerates the two-stage composting of green waste. Bioresour Technol. 2017;243:154-62.

34. Sundberg C, Smårs $\mathrm{S}$, Jönsson H. Low pH as an inhibiting factor in the transition from mesophilic to thermophilic phase in composting. Bioresour Technol. 2004;95:145-50.

35. de Bertoldi M, Vallini G, Pera A. The biology of composting: A review. Waste Manag Res. 1983;1:15776.

36. Zhang L, Sun X. Effects of earthworm casts and zeolite on the two-stage composting of green waste. Waste Manag. 2015;39:119-29.

37. Hargreaves JC, Adl MS, Warman PR. A review of the use of composted municipal solid waste in agriculture. Agric Ecosyst Environ. 2008;123:1-14.

38. Tiquia SM. Reduction of compost phytotoxicity during the process of decomposition. Chemosphere. 2010;79:506-12.

39. Dimambro ME, Lillywhite RD, Rahn CR. Biodegradable municipal waste composts: analysis and application to agriculture. Onyx Environmental Trust \& Defra; 2005.

40. Luo Y, Liang J, Zeng G, Chen M, Mo D, Li G, et al. Seed germination test for toxicity evaluation of compost: Its roles, problems and prospects. Waste Manag. 2018;71:109-14.

41. Zeng GM, Huang HL, Huang DL, Yuan XZ, Jiang RQ, Yu M, et al. Effect of inoculating white-rot fungus during different phases on the compost maturity of agricultural wastes. Process Biochem. 2009;44(4):396-400.

42. Tiquia S. Microbiological parameters as indicators of compost maturity. J Appl Microbiol. 2005;99:816-828.

43. Mkhabela MS, Warman PR. The influence of municipal solid waste compost on yield, soil phosphorus availability and uptake by two vegetable crops grown in a Pugwash sandy loam soil in Nova Scotia. Agric Ecosyst Environ. 2005;106:57-67.

44. Li R, Wang JJ, Zhang Z, Shen F, Zhang GJ, Qin R, et al. Nutrient transformations during composting of pig manure with bentonite. Bioresour Technol. 2012;121:362-68.

45. Wong JWC, Fung SO, Selvam A. Coal fly ash and lime addition enhances the rate and efficiency of decomposition of food waste during composting. Bioresour Technol. 2009;100:3324-31.

46. Boldrin A, Andersen JK, Christensen TH. LCA Report: Environmental Assessment of Garden Waste Management in Arhus Kommune. Copenhagen: Technical University of Denmark; 2009.

47. Naher UA, Sarkar MIU, Jahan A, Biswas JC. Co-Composting Urban Waste, Plant Residues, and Rock Phosphate: Biochemical Characterization and Evaluation of Compost Maturity. Commun Soil Sci Plant Anal. 2018;49:751-62. 
48. Wang L, Zhang Y, Lian J, Chao J, Gao Y, Yang F, et al. Impact of fly ash and phosphatic rock on metal stabilization and bioavailability during sewage sludge vermicomposting. Bioresour Technol. 2013;136:281-87.

49. Mhindu RL, Wuta M, Ngorima E. Composting of selected organic wastes from peri-urban areas of Harare, Zimbabwe. Int J Recycl Org Waste Agric. 2013;2:14.

50. Rawoteea SA, Mudhoo A, Kumar S. Co-composting of vegetable wastes and carton: Effect of carton composition and parameter variations. Bioresour Technol. 2017;227:171-78.

51. Khan KS, Joergensen RG. Changes in microbial biomass and $P$ fractions in biogenic household waste compost amended with inorganic $P$ fertilizers. Bioresour Technol. 2009;100:303-09.

52. Sharif M, Matiullah K, Tanvir B, Shah AH, Wahid F. Response of fed dung composted with rock phosphate on yield and phosphorus and nitrogen uptake of maize crop. African J Biotechnol. 2011;10:12595-601.

53. Billah $\mathrm{M}$, Bano A. Role of plant growth promoting rhizobacteria in modulating the efficiency of poultry litter composting with rock phosphate and its effect on growth and yield of wheat. Waste Manag Res. 2015;33:63-72.

\section{Figures}

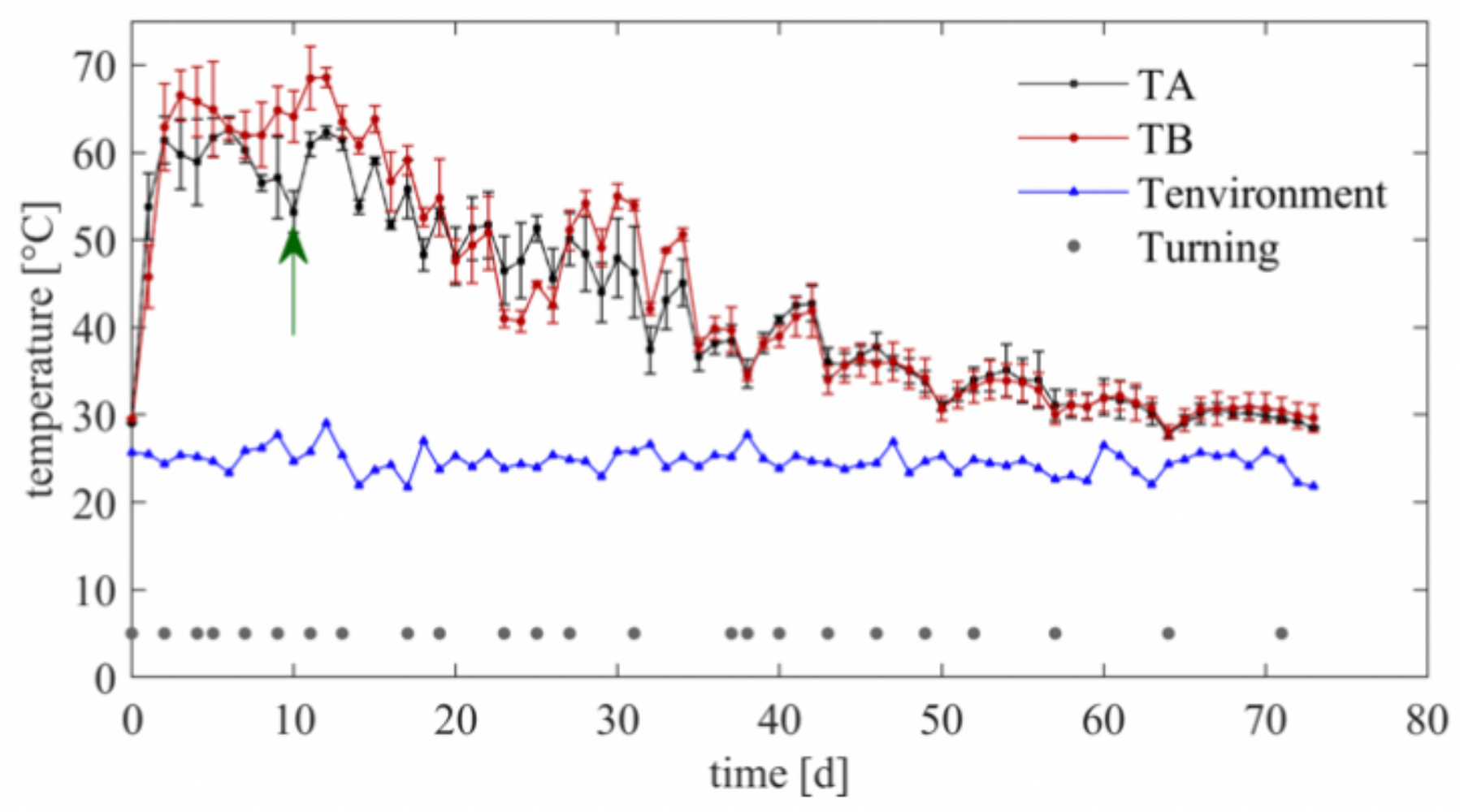

Figure 1 
Temperature behavior in the experiment. Note: Error bars indicates standard deviation (number of replications=3). The green vertical arrow means that at TA (TSC) the material was removed from the containers and piled in conical heaps.

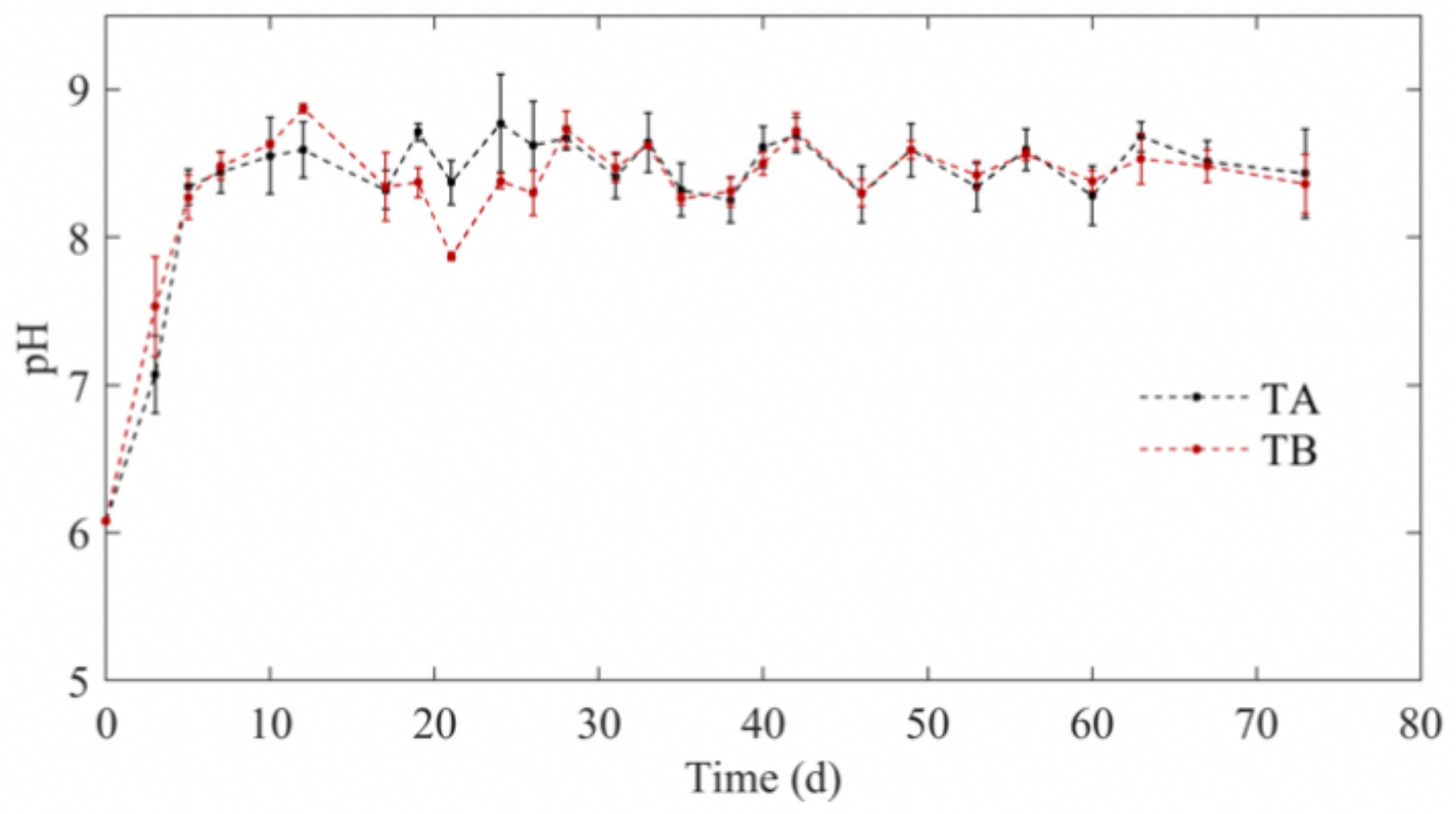

Figure 2

$\mathrm{pH}$ behavior in the two treatments (number of replications=3) 


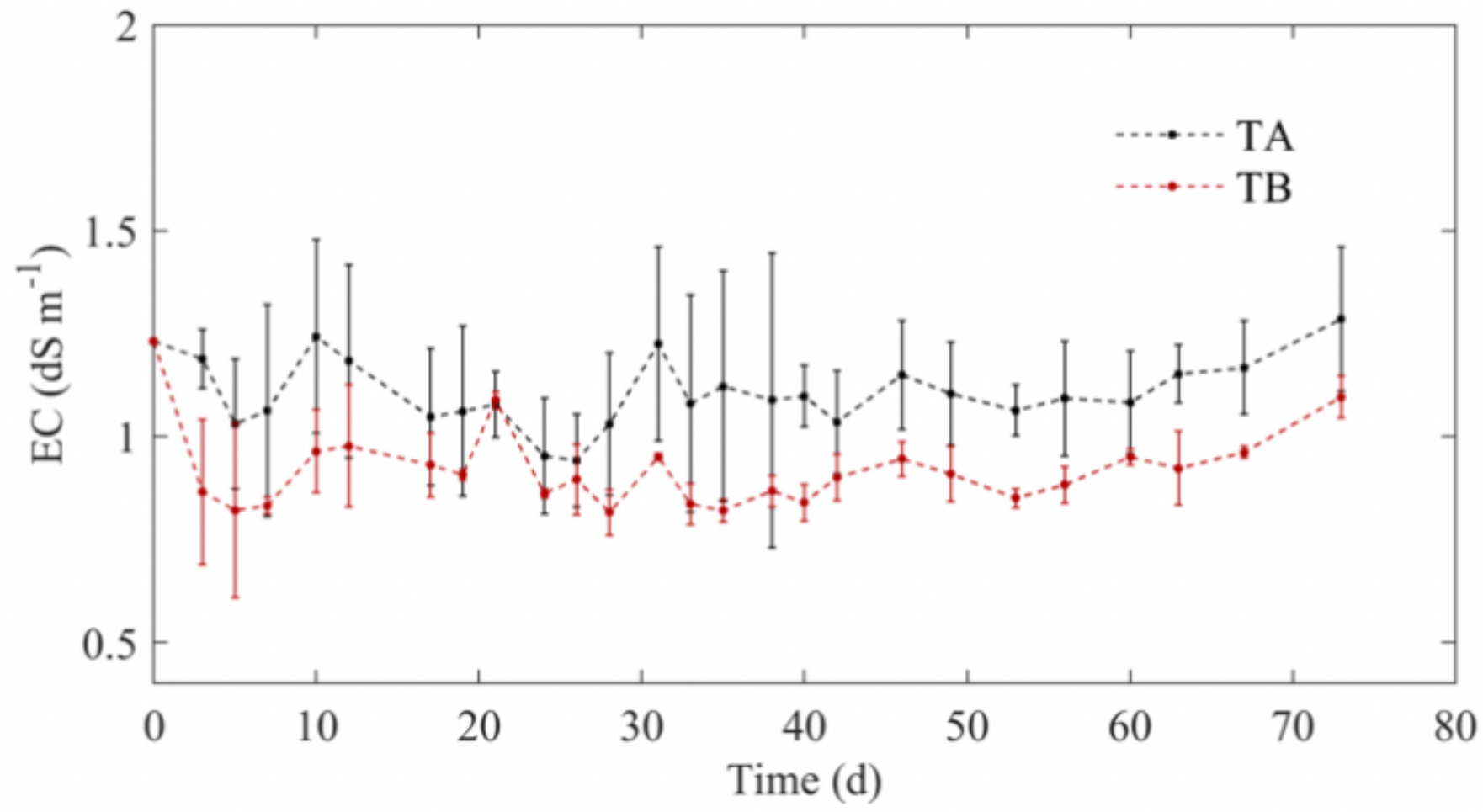

Figure 3

EC behavior in both treatments (number of replications=3) 